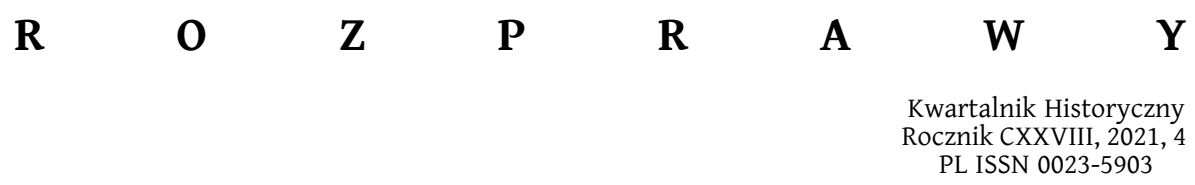

\author{
RAFAŁ RUTKOWSKI \\ https://orcid.org/0000-0002-1875-982X \\ Instytut Archeologii i Etnologii PAN
}

\title{
ZWYCIĘSTWO BEZ WALKI I WOJOWNICY UDAJĄCY KUPCÓW. PODSTĘP OLAFA ŚWIĘTEGO W SAUDUNGSSUNDZIE
}

\begin{abstract}
Abstrakt: Przedmiotem artykułu jest zanotowana w kronice Mnicha Teodoryka i sagach królewskich opowieść o potyczce św. Olafa i jarla Haakona Erikssona w Saudungssundzie (ok. 1015 r.). W ramach analizy porównawczej podkreślono trzy jej aspekty: bezkrwawy charakter, podstęp z zatrzymaniem statków rozciągniętymi linami, a przede wszystkim wprowadzenie Haakona w błąd przez udających kupców ludzi Olafa.
\end{abstract}

Słowa kluczowe: św. Olaf, sagi królewskie, epika średniowieczna, przebrania, podstępy wojenne.
Abstract: The subject of the article is the story of the skirmish between St Olaf and Jarl Hákon Eriksson at Saudungssund (c. 1015) as recorded in Theodoricus Monachus' Chronicle and the royal sagas. The comparative analysis highlights three aspects of the encounter: its bloodless nature, the deceit of stopping the ships with stretched ropes, and above all, the deception of Hákon by Olaf's people posing as merchants.

Keywords: St Olaf, Kings Sagas, medieval epic, disguises, war subterfuges.

PRIAM (do domownika): Co jest za jeden, jaki, jak ubrany?

HEKABE: Przekupień, często przynosi świecidła, |

które sprzedają nam tamci z obozu, | a w zamian bierze nasze

PARYS: Szpieg, powiesić

HEKABE: Znam go dobrze i z dawna; Grek pewien spokojny; |

handluje drobnostkami, jest bardzo przystojny. | A miłyć zawsze widok człowieka grzecznego | Dopuścić go bezpiecznie. Powie co nowego ${ }^{1}$

${ }^{1}$ Reakcje na przybycie do domostwa Priama przebranego w strój kupiecki Tersytesa (S. Wyspiański, Achilleis. Sceny dramatyczne, Kraków 1903, scena VIII, s. 62 n.). 
U progu swego panowania Olaf Święty stoczył dwie zwycięskie bitwy morskie z jarlami Hladir: w Saudungssundzie z Haakonem Młodszym i pod Nesjar z jego stryjem Swenem. Zajmuje mnie pierwsza z nich, mało spektakularna pod względem militarnym, bardziej potyczka czy zasadzka niż bitwa. Skromny z pozoru epizod jako jeden z nielicznych znalazł jednak miejsce w najdawniejszej tradycji historycznej związanej z Olafem. Zwycięstwo odniesione zarazem podstępem, jak i bez walki, może stanowić przyczynek do badań nad świętością władców we wczesnym średniowieczu (mówiąc precyzyjnie - ich stosunkiem do przemocy), jak również do analizy konwencji literackich i ówczesnych wyobrażeń o podziałach społecznych, konkretnie - o naturze kupców i wojowników. Pokażę, jakiego fortelu użył wówczas Olaf, by skutecznie i bezkrwawo pokonać Haakona. W przekazach nacisk został położony na moment, w którym norweski król rozciągnął liny w poprzek cieśniny tak, by zatrzymać wraże łodzie. Baczniejsza lektura pozwala jednak dostrzec, że jarl dał się złapać w zasadzkę, ponieważ wojownicy Olafa udawali kupców. Mimo to problem ten kompletnie umknął uwadze badaczy dziejów skandynawskiego średniowiecza. Rzecz zasygnalizowaną w innym miejscu ${ }^{2}$, rozwijam poniżej.

Chcę dowieść, że mylne wrażenie, które odniósł jarl Haakon, nie było przypadkowe, tylko stanowiło zamierzony przez Olafa element zasadzki. Przebranie kupieckie jest bowiem dobrze potwierdzonym w literaturze starożytnej i średniowiecznej kamuflażem stosowanym przez wojowników i rycerzy pragnących zmylić przeciwnika. Najstarsza, lakoniczna wzmianka pojawia się już u Herodota na marginesie opowieści o konsekwencjach, jakie spotkały Lacedemończyków po wrzuceniu posłów Dariusza do studni. Jak czytamy, Sperchies - ojciec spartańskiego posła, który udał się z przebłagalną misją na dwór Kserksesa - „zdobył założone przez Tiryntyjczyków miasto Haliejs, dopłynąwszy tam z liczną załogą statku ciężarowego"3. Kolejne przykłady można znaleźć nie tylko w źródłach $\mathrm{z}$ różnych epok, ale również z różnych stron świata indoeuropejskiego, w tym ze Skandynawii. Wykorzystane przeze mnie przekazy, niekiedy bardzo różne, łączy to, że występują w nich wojownicy przebrani za kupców, postaram się jednak znaleźć w nich więcej prawidłowości. Materiał porównawczy - który po części zawdzięczam Aleksandrowi Orłowowi (Aleksandr Orlov'), Marcelowi Meulderowi i Sharon Kinoshicie ${ }^{4}-$

${ }^{2}$ R. Rutkowski, Norweska kronika Mnicha Teodoryka. Północna tradycja historyczna wprowadzona w nurt dziejów powszechnych (koniec XII wieku), Toruń 2019, s. 276.

${ }^{3}$ Herodot, Dzieje, tłum. S. Hammer, Warszawa 1954, lib. VII, cap. 137, s. 500.

${ }^{4}$ А.С. Орловъ, Сказочныя повъсти объ Азовъ. „Исторія” 7135 года, Варшава 1906, s. 158-227; M. Meulder, Le „cheval de Troie” sous une autre forme. Le guerrier déguisé en marchand. Exemples antiques et médiévaux, „Nouvelle Mythologie Comparée” 2013, 1, s. 1-42; 
obejmuje przekazy nie tylko historiograficzne, ale również literackie takie jak choćby Kudrun, Charroi de Nîmes czy Dekameron. Stąd nie sposób traktować interesującego mnie podstępu jako elementu dawnej sztuki wojennej, tylko motyw par excellence literacki ${ }^{5}$. Aby go zbadać, użyje metody komparatystycznej: z jednej strony zastanowię się, w jaki sposób i z jakich elementów powinna być zbudowana opowieść o wojownikach przebranych za kupców oraz jakie treści ze sobą niosła; z drugiej zaś sprawdzę, na ile potencjał tego typu narracji został wykorzystany w historii o potyczce Olafa z jarlem Haakonem.

Celem takiej analizy nie jest skatalogowanie wszystkich dostępnych przekazów, jakby wzorem Frontyna czy Poliajnosa, ani prześledzenie zapożyczeń literackich (są one nieistotne z punktu widzenia analizy, nie sposób zresztą udowodnić, że większość przywoływanych przekazów była wzajemnie zależna). Weryfikacji poddany zostanie natomiast stereotypowy pogląd, wedle którego granica między światem kupieckim a wojowniczym była płynna i cienka. Średniowieczni wojownicy mieliby dokonywać łupiestw i grabieży, a zdobyte tą drogą dobra przeznaczać na sprzedaż. Być może tak działo się w rzeczywistości, inaczej sprawa wygląda w świecie przedstawionym źródeł narracyjnych, który interesuje mnie w tym tekście. W świetle analizowanego materiału handel i wojna okazują się bowiem zajęciami, których nie powinna podejmować jedna i ta sama postać literacka, ponieważ nie mieściło się to w jej właściwościach. Niezgodność zajęć handlowych z wojennymi została bez ogródek wyłożona w przypisywanym św. Tomaszowi z Akwinu traktacie 0 królowaniu - królowi Cypru. Na marginesie wywodów o autarkii gospodarczej stwierdzono tam, że kupcy, przez to, że zwykli pławić się w luksusach, są słabi na ciele i na duchu, i nie nadają się do walki zbrojnej. Z tego właśnie względu, by uchronić żołnierzy przed demoralizującym wpływem handlu, prawo cywilne zabrania im angażować się w tego typu działalność 6 . To wszystko

Sh. Kinoshita, Romance in/and the Medieval Mediterranean, w: Thinking Medieval Romance, red. K.C. Little, N. McDonald, Oxford, UK-New York 2018, s. 193. Ponadto: J. Renard, Islam and the Heroic Image. Themes in Literature and the Visual Arts, Macon, GA 1999, s. 145. Przykład z malarstwa barokowego, zob. R.B.K. McLanathan, „Achilles on Skyros” by Nicolas Poussin, „Bulletin of the Museum of Fine Arts” 45, 1947, 259, s. 8 n.

${ }^{5}$ Nie sposób np. twierdzić, że historyczny Saladyn w przebraniu kupca naprawdę udał się na szpiegowską wyprawę do Italii. Na temat dzieła Boccaccia jako źródła historycznego, zob. H. Manikowska, Topos czy rzeczywistość? O czarnej śmierci w Dekameronie raz jeszcze, St. Źr. 53, 2015, s. 17-54.

6 „Est autem negotiationis usus contrarius quam plurimum exercitio militari. Negotiatores enim dum umbram colunt, a laboribus vacant, et dum fruuntur deliciis, mollescunt animo, et corpora redduntur debilia et ad labores militares inepta: unde secundum iura civilia negotiatio est militibus interdicta", Thomas de Aquino, De regimine 
prowadzi do kolejnego problemu: jest nim związek między strojem (czy szerzej atrybutem), a tożsamością społeczną postaci: „szata czyni człowieka", objawia i określa prawdziwą naturę tego, kto ją nosi, i choć może być dowolnie zmieniana, nie zawsze jest w stanie go przeobrazićp. Rodzi się zatem pytanie, co się wydarzy, gdy ktoś przynależny do określonej kategorii założy strój niezgodny ze swoją naturą? Czyż nie wygeneruje to swoistego dysonansu, niezgodności między postacią a atrybutem? Można ów dysonans odczytywać po dumézilowsku, jako efekt transgresji przedstawiciela funkcji drugiej, wojowniczej, do funkcji trzeciej ${ }^{8}$; można też interpretować go w kategoriach bachtinowskiego „świata na opak”.

Jako pierwszy o potyczce w Saudungssundzie opowiada Mnich Teodoryk, autor historii norweskich królów ukończonej między rokiem 1177 a $1188^{10}$. Podaje on, że młody Olaf, przebywając w Anglii, postanowił wyruszyć do Norwegii na dwóch łodziach handlowych („cum duabus onerariis nauibus") wraz ze 120 uzbrojonymi towarzyszami ${ }^{11}$. Po pewnym czasie dopłynął do Saudungssundu, gdzie spędziwszy kilka dni, dowiedział się, że w jego kierunku nadpływają dwie łodzie jarla Haakona ${ }^{12}$. Jak pisze Teodoryk:

principum (De regno ad regem Cypri), w: idem, Opuscula Philosophica, wyd. R.M. Spiazzi, Turin 1954, lib. II, cap. 3, s. 279.

7 Zob. P. von Moos, Das mittelalterliche Kleid als Identitätssymbol und Identifikationsmittel, w: Unverwechselbarkeit. Persönliche Identität und Identifikation in der vormodernen Gesellschaft, red. idem, Köln [etc.] 2004, s. 123-146; M.R. Pauk, Habitus facit hominem wprowadzenie do problematyki społecznych funkcji ubioru w epoce przednowoczesnej, w: Habitus facit hominem. Społeczne funkcje ubioru w średniowieczu i w epoce nowożytnej, red. E. Wółkiewicz, M. Saczyńska, M.R. Pauk, Warszawa 2016, s. 7-17; A. Adamska, „Czy Pan wie, kto ja jestem?". Kilka uwag o mechanizmach percepcji wzrokowej i skuteczności kodów westymentarnych w późnośredniowiecznej Europie, w: ibidem, s. 19-34. Dopiero na etapie korekty miałem możliwość zapoznania się ze zbiorem studiów: Masques et déguisements dans la littérature médiévale, red. M.-L. Ollier, Montréal-Paris 1988.

${ }^{8}$ Por. np. D. Dubuisson, Twentieth Century Mythologies. Dumézil, Lévi-Strauss, Eliade, London-New York 2014, s. 55 n.

9 Zob. L.R. Perfetti, Dialogue of Laughter. Bakhtin's Theory of Carnival and the Charroi de Nîmes, „Olifant” 17, 1993, 3-4, s. 177-195.

${ }^{10}$ Znakomite wprowadzenie do lektury kroniki stanowią: S. Bagge, Theodoricus Monachus - Clerical Historiography in Twelfth-Century Norway, "Scandinavian Journal of History" 14, 1989, 2, s. 113-133; P. Foote, Introduction, w: Theodoricus Monachus, An Account of the Ancient History of the Norwegian Kings, tłum. D. McDougall, I. McDougall, London 1998, s. VII-XXXI.

11 ,parauit Olauus iter suum in Norwagiam cum duabus onerariis nauibus et sociis apprime armatis, qui dicuntur fuisse centum uiginti omnes loricati", Theodoricus, De antiquitate regum Norwagiensium. On the Old Norwegian Kings, wyd. E. Kraggerud, tłum. P. Fisher, Oslo 2018, cap. 15, s. 48.

12 Ibidem. 
powiadomiony o tym, nasz Olaf obmyślił taką oto zasadzkę: umieścił swoje łodzie na przeciwległych brzegach, a ponieważ było to w najwęższym miejscu cieśniny, rozciągnął między nimi liny, które miały być zasłonięte przez fale w taki sposób, aby nie zdradzić zasadzki, dopóki wrogowie nie wpadną w nią przez swoją nieostrożność. Dzięki temu mogli oni zostać schwytani w miarę możliwości nietknięci i bez rozlewu krwi. I tak też się stało; kiedy bowiem przybył Haakon, nie spodziewał się nikogo innego niż kupców, i wnet został schwytany przez króla. Wyrzekł się tam wówczas całej dzielnicy Norwegii, którą sam dzierżył, a stamtąd wyruszył do Anglii ${ }^{13}$.

W opowieści Teodoryka na plan pierwszy wysunięte zostały dwa aspekty potyczki: po pierwsze, jej bezkrwawy charakter, a po drugie, przygotowanie podstępu z linami. Kronikarz wprost nazywa rzecz „zasadzką" (laqueus, dolum), ale zaznacza, że była ona tak pomyślana, by pokonanie wrogów odbyło się bez rozlewu krwi (,illesi et sine sanguinis effusione"). To bardzo interesujące usprawiedliwienie podstępu. Wielki król - a nie ma najmniejszych wątpliwości, że kimś takim w oczach Teodoryka był właśnie Olaf - powinien zawsze otwarcie stawać do walki ${ }^{14}$. Tymczasem zaatakował on skrycie i bez wypowiedzenia wojny. Nie chodzi tu o przewagę liczebną przeciwnika, skoro siły obydwu władców były wyrównane (każdy dysponował bowiem dwiema łodziami). Clou stanowi etyczna postawa króla, która nie tylko ma oddalić ewentualne zarzuty o atak z zaskoczenia, ale w ogóle ukrócić wszelkie próby ich sformułowania ${ }^{15}$. Taki sposób postępowania jest zresztą charakterystyczny dla całego wizerunku Haraldssona na kartach kroniki: na przykład w wygranej bitwie morskiej pod Tunga (Tungenes), stoczonej z wodzem Erlingiem, Olaf zamierzał puścić go wolno, ten jednak został

13 „Quo comperto Olauus noster excogitauit huiusmodi laqueum: Fecit naues suas altrinsecus econtra locari et, quia locus erat angustissimus, cordas inter ipsas naues tendi, que tamen fluctibus operirentur, ne dolum detegerent, ut, dum ibi incauti irretirentur, illesi et sine sanguinis effusione, si fieri posset, caperentur. Quod et ita contigit. Nam adueniens Hacon, nil aliud suspicatus quam mercatores, ilico a rege captus est. Ibi tunc abiurauit totam illam partem Norwagie, quam ipse tenuerat. Inde profectus est in Angliam", ibidem, s. 50 (przekład za: Mnich Teodoryk, O starożytności norweskich królów. De antiquitate regum Norwagiensium, tłum. R. Rutkowski, Toruń 2021, s. 36).

${ }^{14}$ Zob. P. Żmudzki, Władca i wojownicy. Narracje o wodzach, drużynie $i$ wojnach $w$ najdawniejszej historiografii Polski i Rusi, Wrocław 2009, s. 27-88.

${ }^{15}$ Podobnie: S. Bagge, Nordic Uniqueness in the Middle Ages? Political and Literary Aspects, „Gripla” 20, 2009, s. 57; idem, Theodoricus Monachus. The Kingdom of Norway and the History of Salvation, w: Historical Narratives and Christian Identity on a European Periphery. Early History Writing in Northern, East-Central and Eastern Europe (c. 1070-1200), red. I.H. Garipzanov, Turnhout 2011, s. 80. 
wbrew jego woli zabity przez niejakiego Aslaka ${ }^{16}$. Jako władca kierować się miał umiarkowaniem i sprawiedliwością, prześladując jedynie tych, którzy swoją niegodziwością sami skazali się na karę ${ }^{17}$. Prawdziwym traktatem o królewskim „pacyfizmie” jest również opowieść o jego śmierci pod Stiklastadir: Olaf wprawdzie stanął do walki, jednak jego faktycznym celem było umocnienie prawa Bożego i realizacja ewangelicznego nakazu miłowania nieprzyjaciół. Przed bitwą nakazał bowiem swojemu zarządcy, by wypłacił ze skarbca ofiary na msze (ellemosyne) za dusze poległych w walce z nim; przypominał w tym, stwierdza Teodoryk, św. Szczepana, protomęczennika, który przed śmiercią modlił się o zbawienie swoich prześladowców ${ }^{18}$.

Olaf nie był wprawdzie na tyle radykalny, by w ogóle nie podejmować walki, ani też, jak zobaczymy, by nie zabijać wrogów. Niemniej charakterystyczna w jego wypadku była dążność do możliwie bezkrwawego pokonywania przeciwników. Wpisuje się to dobrze w postawę władców świeckich, którzy, jeśli już podejmowali walkę, to starali się stoczyć ją w taki sposób, żeby w jej wyniku żaden z wrogów nie poniósł śmierci: w literaturze przedmiotu najczęściej wymienia się przykłady św. Stefana i św. Geralda z Aurillac ${ }^{19}$. Pierwszy modlitwą do Matki Boskiej pokonał cesarza Konrada $\mathrm{II}^{20}$. O drugim zaś dowiadujemy się, że nigdy nie sięgał po miecz ${ }^{21}$ i nigdy nikogo nie zranił; jego ludzie ruszali bowiem niekiedy do boju, niosąc odwrócone miecze i włócznie (tzn. z rękojeściami i drzewcami skierowanymi w stronę przeciwników), czym wywoływali we wrogach najpierw śmiech, a potem przerażenie ${ }^{22}$. Również Olaf zwyciężył nad

16 Theodoricus, De antiquitate regum Norwagiensium, cap. 16, s. 54.

17 Ibidem, s. 52, 54.

${ }^{18}$ Ibidem, cap. 19, s. 72, 74; por. R. Rutkowski, op. cit., s. 276-278, gdzie dalsza literatura.

19 Zob. np. A. Kuźmiuk-Ciekanowska, Święty i historia. Dynastia Przemyślidów i jej bohaterowie $w$ dziele mnicha Krystiana, Kraków 2007, s. 179-182; P. Żmudzki, Władca i wojownicy, s. 129-132; G. Pac, Problem świętości władców we wczesnym i petnym średniowieczu - przypadek Polski na tle europejskim, „Historia Slavorum Occidentis” 2016, 2 (11), s. $110-113$.

${ }^{20}$ Legenda maior, wyd. E. Szentpétery, Budapestini 1938 (Scriptores rerum Hungaricarum, t. 2), cap. 14, s. 389 n.

${ }^{21}$ S. Odonis abbatis Cluniacensis De Vita s. Geraldi Auriliacensis comitis libri quatuor, PL, t. 133, Parisiis 1881, lib. II, cap. 3, col. 672; por. J. Banaszkiewicz, Atrybuty i społeczne ordines. Kilka obrazków z X-XI wieku, w: idem, Trzy po trzy o dziesiatym wieku, Kraków 2014, s. 237-239.

22 „mucronibus gladiorum retro actis, hastas inantea dirigentes pugnarent”, S. Odonis Vita s. Geraldi, lib. I, cap. 8, col. 646 n.; por. M. Brzozowska, „Mnich czy arystokrata? Wzór świętości w «Żywocie św. Geralda» autorstwa Odona z Cluny”, praca doktorska, Uniwersytet Warszawski, Warszawa 2016, s. 94 n. 
Haakonem bez walki: wystarczyło zatrzymanie łodzi, by ten drugi sam uznał się za pokonanego i zrzekł się władzy. Niespotykane - w każdym razie mnie nie udało się znaleźć żadnej analogii - wydaje się to, że osiągnięciu tego celu służył podstęp, czyli metoda ataku uważana za moralnie wątpliwą. Zamiarowi, jakim było pokonanie przeciwnika, nie towarzyszyła jednak chęć wyprowadzenia go w pole, tylko puszczenia go wolno.

W swoim przekazie Teodoryk wiele uwagi poświęca również temu, jak zasadzka została pomyślana pod względem technicznym. Nie bez znaczenia pozostaje miejsce akcji. Saudungssund (obecnie Sauesund) to niewielka cieśnina w dzisiejszym okręgu Sogn og Fjordane, której wody obmywają południowo-wschodnie wybrzeże wyspy Atløy ${ }^{23}$. Obydwie łodzie Olafa zostały ustawione na przeciwległych brzegach, a między nimi rozciągnięto liny. Były one umieszczone pod wodą, tak aby pozostały niewidoczne dla zbliżającego się przeciwnika. Można się domyślać, że nie tylko zatrzymały one łodzie, ale również wywróciły je; tego dziejopis jednak nie dopowiada. Bardziej zdaje się liczyć dla niego sam pomysł niż realizacja ${ }^{24}$. Opowieść została powtórzona w późniejszej tradycji historycznej. Uchylam się tutaj od rozpoznania filiacji genetycznych łączących przekazy źródłowe ${ }^{25}$, ponieważ bardziej interesują mnie szczegóły, z których skonstruowana została narracja. Przekaz Ágrip, od którego zacznę, jest najbardziej lakoniczny, niemal niezrozumiały ${ }^{26}$. Anonimowy kronikarz z końca XII w. podaje, że Olaf umieścił swoje łodzie po przeciwległych stronach cieśniny, dzięki czemu zatrzymał łodzie jarla („heimtusk brátt skip hans saman”). 0 ile Teodoryk nie dopowiada, jak zadziałał podstęp, to jego młodszy kolega po piórze nie wyjaśnia, w jaki sposób został przygotowany. Nie ma nawet słowa o rozpiętych linach, przez co trudno domyślić się, jak miałoby dojść do zatrzymania łodzi.

${ }^{23}$ Zob. A. Helland, Topografisk-statistik beskrivelse over Nordre Bergenhus Amt, t. 1, Kristiania 1901, s. 813 n.; G. Losnegård, Askvoll during the Viking Period, https://encyclopedia. fylkesarkivet.no/article/95ca4897-6ab8-42a2-a1e9-17cd6c65172a/ (dostęp: 8 XII 2021).

${ }^{24}$ Zob. S. Bagge, Nordic Uniqueness, s. 57; idem, Theodoricus Monachus. The Kingdom, s. 80; E. Kraggerud, w: Theodoricus, De antiquitate regum Norwagiensium, s. 240, przyp. XV.10.

${ }^{25}$ Zob. J. Kristjánsson, Um Fóstbrœðrasögu, Reykjavík 1972, s. 191-201; T. Ulset, Det genetiske forholdet mellom „Ágrip”, „Historia Norwegice” og „Historia de antiquitate regum Norwagiensium". En analyse med utgangpunkt $i$ oversettelsesteknikk samt en diskusjon omkring begrepet „latinisme” i samband med norrøne tekster, Oslo 1983, s. 157 n.; G. Lange, Die Anfänge der isländisch-norwegischen Geschichtsschreibung, Reykjavík 1989, s. 123 n.; D. McDougall, I. McDougall, w: Theodoricus Monachus, An Account of the Ancient, s. 77, przyp. 127; S. Bagge, Nordic Uniqueness, s. 57 n.

${ }^{26}$ Zob. P. Schach, Instant Saga Style. The Evidence of the Manuscripts, ,Journal of English and Germanic Philology" 85, 1986, 3, s. 405. 
Autor Ágrip dodaje jedynie, że Haakon został wraz ze swoimi ludźmi puszczony wolno - co dobrze współgra przecież z „pacyfistycznym” wydźwiękiem opowieści Teodoryka ${ }^{27}$.

Opowieść zaczyna się rozrastać począwszy od przekazu Legendarnej Sagi o św. Olafie. Dowiadujemy się z niej, że przy spotkaniu z naciągniętą liną łodzie jarla wywróciły się ${ }^{28}$. Jeszcze więcej szczegółów przynosi Fagrskinna. Opowieść biegnie podobnym torem jak u Teodoryka aż do momentu, w którym siostrzeniec Kanuta Wielkiego zbliżył się do łodzi Olafa. Wówczas ludzie króla rozciągnęli powróz pod kilem jego łodzi. Gdy się naprężył, zaczęli wykonywać nim ruchy okrężne, a łódź jarla zakołysała się, w efekcie czego jej pokład został zalany. Trudno mówić tu o bezkrwawym zwycięstwie: część ludzi Haakona zginęła od strzał i kamieni, część utonęła i jedynie niektórzy ocaleli. Zwróćmy uwagę na lakoniczne zastrzeżenie Teodoryka, że podstęp Olafa miał uchronić jego wrogów od śmierci „na ile to możliwe” („si fieri posset”). Rzecz rozwinął autor Fagrskinny - nie obyło się bez rozlewu krwi, gdyż było to zwyczajnie niemożliwe. Nie zmienia to faktu, że również wedle relacji sagi Haakona wraz z pozostałymi przy życiu ludźmi puszczono wolno ${ }^{29}$. Snorri Sturluson w Heimskringli nie wnosi dodatkowych szczegółów, poza tym, że okrasza opowieść strofami skaldów ${ }^{30}$.

Podobny podstęp, tyle że z zastosowaniem łańcuchów, pojawia się w utworze, od którego Teodoryk częściej cytował tylko Biblię - czyli w Wojnie domowej Lukana ${ }^{31}$. Być może na niej właśnie wzorował swoją opowieść o starciu Olafa z Haakonem, podobieństwo obu narracji jest w każdym razie zastanawiające. W rzymskim poemacie czytamy, że Antoniusz postanowił uciec przed flotą pompejańską pod wodzą Augusta na trzech tratwach. August, zdając sobie z tego sprawę, nie zaatakował go jednak od razu, tylko zastawił na niego pułapkę w cieśninie iliryjskiej. Przynależała ona do „starej sztuki cylicyjskiej” (antiqua ars Cilix): pod powierzchnią wody ukryto łańcuchy przymocowane do raf - ten właśnie

27 Ágrip af Nóregskonungasogum. A twelfth-century synoptic history of the kings of Norway, wyd. i tłum. M.J. Driscoll, London 2008, cap. 23, s. 36.

28 Olafs Saga hins helga, wyd. O.A. Johnsen, Kristiania 1922, cap. 21, s. 20 n.

${ }^{29}$ Fagrskinna. Nóregs kononga tal, wyd. F. Jónsson, København 1902-1903, cap. 26, s. $144 \mathrm{n}$.

30 Snorri Sturluson, Heimskringla. Nóregs Konunga Sögur, wyd. F. Jónsson, t. 2, København 1893-1900, ól. Helg., cap. 29-30, s. 36-39.

31 Zob. R. Rutkowski, op. cit., s. 100 n., 171; G. Bartusik, „Rómverja Saga - Saga o Rzymianach. Studium nad recepcją kultury łacińskiej w średniowiecznej Skandynawii", praca doktorska, Uniwersytet Śląski w Katowicach, Katowice 2019, s. 167-203, zwłaszcza 168-171 (w obydwu pracach literatura). 
szczegół najbardziej przypomina relację norweskiego kronikarza ${ }^{32}$. Niestety, dwie pierwsze tratwy przepłynęły spokojnie, i dopiero trzecia, dowodzona przez Wultejusza, wpadła w zasadzkę. Załoga bezskutecznie próbowała się z niej wyrwać, ale nie mogąc nic zdziałać, uderzyła o skałę. Wywiązała się krótka potyczka, którą jednak przerwał zmierzch, i dopiero po nastaniu świtu ludzie Augusta ostatecznie rozprawili się z wrogami. Finał starcia był zatem znacznie bardziej krwawy niż tysiąc lat później w Norwegii ${ }^{33}$.

Analogia nie jest pełna z jeszcze jednego powodu. Wspominałem już, że w opowieściach o potyczce w Saudungssundzie najmocniej wyeksponowano wymyślny podstęp z rozpiętymi pod wodą linami. Zauważmy jednak, że - jak donoszą przekazy - Haakon dał się złapać w zasadzkę, ponieważ myślał, iż w sundzie zacumowały łodzie kupieckie: wedle Teodoryka, jarl „nil aliud suspicatus quam mercatores”. Informację tę powtarzają, niczego od siebie nie dodając, sagi królewskie. Przykładowo, w Fagrskinnie czytamy, że bohater „hugði kaupmenn vera i sundinu”. Jedynie w Ágrip brak tego szczegółu, Teodoryk zaś dodaje, że dodatkowym czynnikiem było ukrycie lin pod taflą wody, podobnie jak łańcuchów u Lukana. Omyłka Haakona wydaje się wszakże zrozumiała: czytamy bowiem, że Olaf wyruszył do Norwegii na dwóch łodziach towarowych (naues onerariae; knorrum), których załoga mogła sprawiać wrażenie kupców, a nie wojowników. Te dwie informacje dobrze współgrają ze sobą, działając niczym strzelba Czechowa: jeśli w opowiadaniu wojownicy wsiadają na łodzie towarowe, automatycznie oznacza to, że wrogowie wezmą ich za kupców. Tak właśnie dzieje się w opowieściach Frontyna i Poliajnosa o zdobyciu Sykionu: w obydwu wersjach uzbrojeni Tebanie wsiedli na łodzie kupieckie, by po odwróceniu uwagi przez swoich szturmujących towarzyszy broni spokojnie móc wpłynąć do niestrzeżonego portu ${ }^{34}$. Być może również pierwsi wikingowie, którzy pod koniec VIII w. pojawili się w Wesseksie, przypłynęli tam na łodziach kupieckich. Źródło - a konkretnie kronika Ethelwearda - tego jednak nie dopowiada.

32 „At Pompeianus fraudes innectere ponto | Antiqua parat arte Cilix, passusque vacare | Summa freti medio suspendit vincula ponto | Et laxe fluitare sinit, religatque catenas | Rupis ab Illyricae scopulis”, A Commentary on Lucan, „De bello civili” IV. Introduction, Edition, and Translation, wyd. P. Asso, Berlin-New York 2010, lib. IV, v. 448-452, s. 70. Znajomość tego passusu zawdzięczam Robertowi Kasperskiemu.

${ }^{33}$ Ibidem, s. $68 \mathrm{nn}$.

${ }^{34}$ Frontinus, The Stratagems, wyd. i tłum. C.E. Bennett, London 1925, lib. III, cap. 2, 10, s. 212; Poliajnos, Podstępy wojenne, tłum. M. Borowska, Warszawa 2003, lib. V, cap. 16, 3, s. 224 (o historycznych okolicznościach zdobycia Sykionu, zob. M. Meulder, op. cit., s. 8-12). 
Stwierdza jedynie, że królewski urzędnik, który wyszedł im naprzeciw, dał się zaskoczyć i zabić, ponieważ wziął najeźdźców za kupców ${ }^{35}$.

Sądzę zatem, że pomyłka, której uległ jarl Haakon, nie była dziełem przypadku, tylko z góry zamierzonym przez Olafa efektem. Wzmianki na ten temat są wprawdzie bardzo lakoniczne i można je skwitować jako pozbawione większego znaczenia albo czysto techniczne. Średniowieczni autorzy nie rzucali jednak słów na wiatr i każdy element ich wypowiedzi odgrywa rolę w strukturze opowieści, składając się na określony komunikat; w opowiadaniu - jak wskazuje Roland Barthes - nie ma czegoś takiego jak szumy, nieniosące ze sobą żadnej informacji ${ }^{36}$. Również Georges Dumézil upominał, by nie lekceważyć tego, co w analizowanym tekście wydaje się stanowić drugorzędny, wtórny ozdobnik ${ }^{37}$. Z tego względu z góry należy odrzucić także ewentualną interpretację realistyczną, w świetle której Olaf wyruszył na łodziach kupieckich z myślą o handlu (a która dobrze wpisywałaby się w upowszechniony obraz epoki wikingów) ${ }^{38}$. Kłam zadają jej przede wszystkim wzmianki o tym, kto płynął na owych łodziach i w jaki sposób zostały one ostatecznie wykorzystane ${ }^{39}$. Ponadto, komparatystycznie uchwytny motyw wystawiania towarów na sprzedaż zawsze podporządkowany jest strukturze opowieści o podstępie. Innymi słowy, wojownicy nie po to handlują, by zarobić, tylko po to, by oszukać przeciwnika. Gdy wojownicy króla Hettela dotarli do

35 „putans eos magis negotiatores quam hostes”, Chronicon Æthelweardi, wyd. i tłum. A. Campbell, London [etc.] 1962, lib. III, cap. 1, s. 26 n. (na ten przekaz zwrócił mi uwage anonimowy recenzent artykułu). Opowieść Ethelwearda powstała na kanwie Kroniki Anglosaskiej, w której czytamy jedynie, że królewski urzędnik nie wiedział, z kim ma do czynienia; nie ma tam jednak mowy, by wziął wikingów za kupców, np. w redakcji E: The Anglo-Saxon Chronicle. A collaborative edition, wyd. S. Irvine, t. 7, Ms. E, Cambridge 2004, s.a. 787, s. 41; por. B. Yorke, Wessex in the Early Middle Ages, London-New York 1995, s. 107. Ethelweard uzupełnił zatem przekaz o szczegół narracyjny, który doskonale go dopełnia; wyjaśnia bowiem, skąd wzięło się nieporozumienie.

${ }^{36}$ R. Barthes, Wstęp do analizy strukturalnej opowiadań, tłum. W. Błońska, „Pamiętnik Literacki" 59, 1968, 4, s. 334 n.

${ }^{37}$ G. Dumézil, Bogowie Germanów. Szkice o kształtowaniu się religii skandynawskiej, tłum. A. Gronowska, wstęp J. Banaszkiewicz, Warszawa 2006 (oryg. franc. 1959), s. 28 n.

${ }^{38}$ Zob. np. W. Duczko, Zajęcie? Wiking. O ekonomicznej stronie ekspansji Skandynawów we wczesnym średniowieczu, w: Targi, jarmarki i odpusty. Wykłady popularnonaukowe zorganizowane w ramach X Ogólnopolskiego Festiwalu Kultury Słowiańskiej i Cysterskiej w Lądzie nad Warta w dniach 31 maja - 1 czerwca 2014 roku, red. M. Brzostowicz, M. Przybył, J. Wrzesiński, Poznań-Ląd 2014, s. 43-51; idem, Moce wikingów, t. 1: Światy i zaświaty wczesnośredniowiecznych Skandynawów, Warszawa 2016, s. 44.

${ }^{39}$ Zdaniem Siergieja Agiszewa, obładowane łodzie Olafa nie nadawały się do sprawnego manewrowania podczas kampanii morskiej, С.Ю. Агишев, Теодорик Монах и его „История о древних норвежкских королях”, Москва 2013, s. 180, przyp. 309. 
Irlandii, dokąd wyruszyli po królewnę dla swojego władcy, pierwszą rzeczą jaką zrobili, było rozstawienie targowiska ${ }^{40}$. Podobnie - wedle relacji Sháhnáma - uczynili Rustam w twierdzy na szczycie góry Sipand i Aszfendir w fortecy Tourand: obydwaj szachowie udali się ze swoimi towarami na bazar, by dopiero później przejść do ataku ${ }^{41}$. Oczywiście, był to element kamuflażu. Niedorzecznością byłoby dopatrywać się w tej praktyce jakiegoś aspektu ekonomicznego, niezależnego od całego podstępnego przedsięwzięcia. Nie bez powodu Frontyn zaznacza, że Tebanie przebrali się za kupców, żeby wprowadzić Sykiończyków w błąd (,ut negotiatorum specie fallerent") ${ }^{42}$. Równie wymowne jest stwierdzenie Saxona Gramatyka, że ludzie Daxona, atakując Hvitserka, zrobili to simulata mercatione $e^{43}$. Nie ma tu mowy o żadnej działalności handlowej, chodziło wyłącznie o podstęp.

Historyjka o potyczce w Saudungssundzie nie jest typową opowieścią o wojownikach przebranych za kupców. Mimo że również w innych przekazach występują łodzie (albo inne pojazdy służące do przewozu towarów), to mają one nieco inne zastosowanie. Olaf użył bowiem swojej floty do tego, by wciągnąć wrogów w zasadzkę. W innych przypadkach, jak choćby w zanotowanej przez Alberyka z Trois-Fontaines historii zabójcy św. Engelberta, szło o ucieczkę przed sprawiedliwością ${ }^{44}$. Jeszcze częściej chodziło o to, by samemu niepostrzeżenie dostać się w jakieś niedostępne miejsce, czemu niekiedy towarzyszył podział armii na tych, którzy w przebraniu wchodzili w interakcje z wrogami, i na uzbrojonych, którzy czekali w pogotowiu ${ }^{45}$. W związku z tym niektórzy badacze interpretowali

${ }^{40}$ Kudrun, wyd. K. Stackmann, Tübingen 2000, cap. 5, st. 291 nn., s. 63 nn.

${ }^{41}$ The Sháhnáma of Firdausi, tłum. A.G. Warner, E. Warner, t. 1, London 1905, s. 331 n.; t. 5, London 1910, s. 145 n.

${ }^{42}$ Frontinus, The Stratagems, lib. III, cap. 2, 10, s. 212.

43 Saxo Grammaticus, Gesta Danorum. The History of the Danes, wyd. K. Friis-Jensen, tłum. P. Fisher, t. 1, Oxford 2015, lib. IX, cap. 4, 29-30, s. 654.

${ }^{44}$ Chronica Albrici monachi Trium Fontium, wyd. P. Scheffer-Boichorst, Hannoverae 1874 (MGH SS, t. 23), s.a. 1225, s. 916 n. Grzegorz Bartusik przytacza dwa passusy z islandzkiej Rómverja Sagi, w których Dejotar i Jugurta uciekają ze swoich krajów przebrani za kupców. Jest to amplifikacja opowieści zaczerpniętych od Lukana i Salustiusza (G. Bartusik, op. cit., s. 81 n.). W drugiej dekadzie XVII w. Samuel Korecki uciekł z niewoli tureckiej przebrany za kupca, na co zwrócił mi uwagę Karol Żojdź (Z. Komarnicki, Legenda o ucieczce Samuela Koreckiego z niewoli tureckiej (wyjątek z tomu XV Roczników kościelnych Baroniusza, dopełnionych przez Abrahama Bzowskiego, i z łacińskiego na język polski przełożony, „Biblioteka Warszawska” 61, 1856, 1, s. 186 n.; por. I. Czamańska, Kampania mołdawska Samuela Koreckiego 1615-1616 r., w: Si vis pacem, para bellum. Bezpieczeństwo i polityka Polski. Księga jubileuszowa ofiarowana Profesorowi Tadeuszowi Dubickiemu, red. R. Majzner, Częstochowa-Włocławek 2013, s. 138, zwłaszcza przyp. 63).

${ }^{45}$ Tak dzieje się np. w przekazie Saxona Gramatyka o najeździe Słowian na Roskilde. Niejaki Radulf ścigał ich, a niekiedy przed nimi uciekał, podając się za kupca, który 
omawiany fortel jako odmianę konia trojańskiego ${ }^{46}$. Tak dzieje się w przekazie Herodota, przedstawiającym okoliczności wpłynięcia Sperchiesa do Haliejs, jak również w katalogach podstępów spisanych przez Frontyna i Poliajnosa, dotyczących zdobycia Sykionu przez Teban. W taki sam sposób, wedle rzymskiego intelektualisty, postąpili także Spartanie pod wodzą Arystypa. Wykorzystując uroczystości ku czci Minerwy, przebrali się za kupców i wprowadzili za mury Tegei zwierzęta objuczone workami, by następnie wpuścić tam swoich towarzyszy broni ${ }^{47}$. Podobną, cytowaną już opowieść przytacza Saxo Gramatyk: Hvitserk, jeden z synów Ragnara Lodbroka, został w niej podstępnie zaatakowany przez Daxona. Otóż syn władcy Hellespontu pod pozorem rozmów pokojowych wprowadził do miasta wojowników, którzy byli przebrani za kupców ${ }^{48}$. Taki kamuflaż wcale nie ułatwił im walki, pozwolił jedynie przekroczyć mury miejskie. Doszło wówczas do niezwykle krwawej potyczki, którą - pomimo stawionego przez siebie oporu - Hvitserk przegrał ${ }^{49}$. Do wrogów w podobny

wymienia konie na broń. Oczekiwał w ten sposób na przybycie wolniejszej, ale w pełni uzbrojonej armii duńskiej („Interrogatus, quis esset, mercatorem respondit. Percontantibus, quasnam merces haberet, respondit arma, quibus equos commutare soleret", Saxo Grammaticus, Gesta Danorum, t. 2, lib. XIV, cap. 15, 1-3, s. 1056, 1058, 1060). Z kolei gdy przebrany za kupca szach Ardaszir wkradł się do twierdzy, by napoić ołowiem cudownego robaka, który przynosił szczęście Haftwadowi, jego siły czekały w pogotowiu za murami (The Sháhnáma of Firdausi, t. 6, London 1912, s. 239-245).

${ }^{46}$ Zob. np. M. Meulder, op. cit., passim (James George Frazer, na którego powołuje się Meulder, nie przytoczył przekazu, w którym wojownicy udawaliby kupców, tylko wczesnonowożytny casus wprowadzenia niderlandzkich żołnierzy do Bredy na statku załadowanym torfem, zob. J.G. Frazer, w: Apollodorus, The Library, t. 2, London 1921, s. 229-231, przyp. 1). Ponadto: Sh. Kinoshita, Beyond Philology. Cross-Cultural Engagement in Literary History and Beyond, w: A Sea of Languages. Rethinking the Arabic Role in Medieval Literary History, red. S. Conklin Akbari, K. Mallette, Toronto-Buffalo 2013, s. 33; J. Jacobs, An Inheritance of Violence: Patrimony, Vassal Service, and Conquest in the Charroi de Nîmes, „Exemplaria” 24, 2012, 4, s. 304.

47 „Aristippus Lacedaemonius festo die Tegeatarum, quo omnis multitudo ad celebrandum Minervae sacrum urbe egressa erat, iumenta saccis frumentariis palea refertis onusta Tegeam misit, agentibus ea militibus, qui negotiatorum specie inobservati portas aperuerunt suis", Frontinus, The Stratagems, lib. III, cap. 2, 8, s. 210; por. W. Michalski, Robert Bruce i jego kompania w eposie pióra Johna Barboura. The Bruce około 1376 roku, Lublin 2020, s. 192, gdzie również przykład szkocki.

48 „Interea Daxon Withsercum Scithie principantem diu nequicquam superare conatus tandem ficte pacis commento circumuentum aggreditur. Conuiuialiter ab eo exceptus armatum subornauit exercitum, qui simulata mercatione in urbem rhedis aduectus hospitis domum nocturno laceraret assultu", Saxo Grammaticus, Gesta Danorum, t. 1, lib. IX, сар. 4, 29-30, s. 654; por. Е.А. Рыдзевская, К вопросу об устных преданиях в составе древнейшей русской летописи, w: eadem, Древняя Русь и Скандинавия IX-XIV в8., Москва 1978, s. 176-178.

49 Saxo Grammaticus, Gesta Danorum, t. 1, lib. IX, cap. 4, 30, s. 654. 
sposób zakradł się również jeden z głównych bohaterów Sagi o Njálu, Gunnar. Jego podstęp nie miał wprawdzie charakteru militarnego, tylko prawny, co jednak nie zmienia istoty rzeczy. Miało to na celu zmuszenie niejakiego Hoskulda do wypowiedzenia mimochodem formuły pozwalającej wznowić proces o posag należny jego byłej żonie. Gunnar przybył do jego domu, podając się za Kaupa-Hedinna, nieokrzesanego handlarza żelastwem ${ }^{50}$.

Opowieść Teodoryka przypomina pod pewnymi względami znaną w dwóch wersjach historię o opanowaniu Kijowa przez Rurykowiczów ${ }^{51}$. Jej protagoniści nie wkradli się bowiem do miasta, tylko wręcz przeciwnie, wywabili z niego wrogów. Jak czytamy w Powieści lat minionych, Oleg, który był krewnym Ruryka i wyznaczonym przezeń opiekunem małoletniego Igora, zwerbował armię z ludów zamieszkujących Ruś i wraz z nią opanował Smoleńsk i Lubecz. Następnie skierował się ku Kijowowi, nad którym kontrolę sprawowali Askold i Dir. I tym razem armia została podzielona: dowódca wraz z młodocianym Igorem przebrali się za kupców (a przynajmniej za takich się podawali - „Гость есмь”) i zadeklarowali pokojowe zamiary, dzięki czemu mogli zwabić niczego niespodziewających się wrogów na Wzgórze Wareskie. Część wojska została w tyle, a resztę Oleg zabrał ze sobą, chowając ich w łodziach. Ujawnili się oni dopiero, gdy na miejscu pojawili się Askold i Dir. Wówczas bohater oznajmił, że wrogowie, w przeciwieństwie do niego, nie mogą szczycić się prawowitym pochodzeniem dynastycznym i zabił ich ${ }^{52}$. Podobnie przedstawiono przebieg wypadków w prawdopodobnie starszej wersji,

${ }^{50}$ Brennu-Njálssaga (Njála), wyd. F. Jónsson, Altnordische Saga Bibliothek, Halle a.S. 1908, cap. 21-23, s. 50-56; por. L. Lönnroth, Njáls Saga. A Critical Introduction, Berkeley 1976, s. 203 (którego zdaniem, negatywny wizerunek Hedinna świadczy o tym, że autor sagi nie mógł wywodzić się z kupiectwa). Przekaz ten zasługiwałby na szersze rozwinięcie. Tutaj zwrócę jedynie uwagę na to, że Hoskuld został zmuszony do wypowiedzenia formuły prawnej i zrobił to mimochodem; miała ona jednak swoją moc - każde słowa wypowiedziane na głos stawały się wiążące dla mówiącego, nawet wbrew jego intencjom. Podobnie dzieje się w innej opowieści osnutej wokół motywu przebrania, tzn. w micie etnogenetycznym Longobardów. Wodan stał się tam bóstwem opiekuńczym Winulów po tym, jak widząc ich kobiety z włosami zaczesanymi tak, by wyglądały jak brody, spytał od niechcenia, kim są ci długobrodzi? („Qui sunt isti longibarbae?”). Bogini Freya, będąca inicjatorką podstępu, odpowiedziała wówczas, że skoro nadał temu ludowi nowe imię („Longobardowie”), powinien dać im również zwycięstwo w nadchodzącej walce z Wandalami (Origo gentis Langobardorum, wyd. G. Waitz, Hannoverae 1878 [MGH Scriptores rerum Langobardicarum, t. 1], s. 2 n.).

51 Zob. Е.А. Рыдзевская, op. cit., s. 176-178; П.П. Толочко, Двориовые интриги на Руси, Киев 2001, s. 16-19.

52 Повєсть временныхъ лєт, wyd. Д.С. Лихачев, Москва-Ленинград 1950, s.a. 6390 (882), s. 20. 
przekazanej przez Pierwszy Latopis Nowogrodzki. Z jedną istotną różnicą. Protagonistą, który pokonał Askolda i Dira, był dorosły już Igor, któremu Oleg jedynie towarzyszy1 ${ }^{13}$. Podstępu nie dokonał zatem urzędnik drugi po władcy, dla którego tego typu działanie byłoby rzeczą naturalną, tylko władca, któremu tak postępować się nie godzi ${ }^{54}$. A w grę nie wchodziło tu przecież - inaczej niż podczas starcia u wybrzeży Atløy - ocalenie wrogów, tylko wręcz przeciwnie, ich wyeliminowanie. Istotne jest natomiast to, że kupiecka przykrywka posłużyła Olegowi i Igorowi do zwabienia przeciwników w zasadzkę, a nie wdarciu się za mury miejskie. Właśnie ten aspekt opowieści latopisarskiej przypomina podstęp Olafa. Być może nie bez znaczenia jest również to, że zarówno norweski, jak i ruski monarcha szczycili się prawowitym pochodzeniem dynastycznym, podstęp zaś służył im do odsunięcia od władzy uzurpatorów.

Zgromadzone powyżej przekazy można potraktować jako barwne (i w gruncie rzeczy banalne) opowieści o sprytnym podstępie. Pokazują one jednak stopień rozpowszechnienia motywu, a także, w jaki sposób i z jakich elementów powinna być zbudowana narracja o wojownikach udających kupców. Już z tego względu zasługują na uwagę przy rozpatrywaniu epizodu związanego z Olafem, pozwalają bowiem zaklasyfikować go do szerszego spektrum opowieści o charakterze historyczno-batalistycznym. To już wiele. Aby jednak wzmocnić i doprecyzować płynące z tego zestawienia wnioski, warto sięgnąć do kolejnych przekazów, które odsłonią głębsze treści wpisane w interesujący nas podstęp. Pokażą mianowicie, że sens takiego działania był nie tylko pragmatyczny, ale i symboliczny, przesądzając tym samym, że i Olaf nie był żadnym kupcem, tylko takiego udawał. Istotą opowieści o wojownikach przebranych za kupców wydaje się zatem nieprzystawalność zajęć związanych z wojną i handlem, a kluczowym motywem w nich występującym - demaskacja takich „kupców”.

Najsłynniejszym bohaterem tego typu był z całą pewnością Wilhelm z Orange, którego losy przedstawiono m.in. w dwunastowiecznym eposie Charroi de Nîmes ${ }^{55}$. Rycerz, aby wykazać się przed królem Ludwikiem,

53 Новгородская Первая Летопись, wyd. А.Н. Насонов, Москва-Ленинград 1950, s. 107, gdzie Igor i Oleg „творящася подугорьскыми гостьми”.

54 Zob. P. Żmudzki, Władca i wojownicy, s. 55 n., 451 n.

${ }^{55} \mathrm{Z}$ przebogatej literatury, zob. D. Maddox, S. Sturm-Maddox, Inter textual Discourse in the William Cycle, "Olifant” 7, 1979, 2, s. 136, 140 n.; F. Suard, Le Motif du déguisement dans quelques chansons du cycle de Guillaume d'Orange, "Olifant” 7, 1980, 4, s. 343-358; L.R. Perfetti, op. cit., passim; E.J. Burns, Sea of Silk. A Textile Geography of Women's Work in Medieval French Literature, Philadelphia 2009, s. 28 n.; G. Tanase, Le marchand et la Sarassin - des miroirs déformants de Guillaume d'Orange?, http://french.chass.utoronto. 
postanowił wyruszyć wraz z doborowym oddziałem na wyprawę do Nîmes. Miasto było opanowane przez Saracenów i pozostawało praktycznie nie do zdobycia. Jeden z rycerzy obmyślił plan, by Wilhelm, przebrany za kupca, wwiózł tam swoich ludzi ukrytych w beczkach. Tak właśnie zrobił. Wilhelm przedstawił się jako Tiacre, kupiec z Canterbury. Zapytany przez saraceńskiego króla, Otranta, czym handluje, odparł, że tkaninami i ozdobami, a także uzbrojeniem (a pamiętajmy, że w to ostatnie wojownicy Wilhelma byli naprawdę wyposażeni). Słowa te przekonały władcę i dobrze usposobiły do przybyszy. Zaczął wypytywać Wilhelma o jego relacje rodzinne i szlaki handlowe, które zwykł przemierzać. W pewnym momencie Otrant omal nie rozpoznał jednak Wilhelma po jego charakterystycznym krótkim nosie (którego czubek stracił w bitwie z niewiernymi). Bohater tymczasowo uśpił jego czujność, wyjaśniając, że w młodości ucięto mu nos, karząc go za dokonane kradzieże. Wówczas jednak pojawił się seneszal Barre, który poskarżył się królowi, że kupcy zablokowali wejście do pałacu. Zwrócił też uwagę, że nie chcą obdarować go przywiezionymi przez siebie towarami. Zażądał wobec tego zarżnięcia dwóch wołów, które były zaprzęgnięte do wozów kupieckich, i ugotowania z nich strawy. Tak też się stało, co bardzo zaniepokoiło Wilhelma. Powiadomił on zatem Saracenów, że zamierza opuścić miasto. Na co drugi z miejscowych władców, Harpin, wytargał rycerza za brodę, czym niezmiernie go uraził: nawet jeśli Wilhelm nosił ubranie nieodpowiednie do swojego statusu, wciąż pozostawał szlachetnym rycerzem, którego nie godziło się znieważać w taki sposób. W tej sytuacji ujawnił się, przy pomocy ukrytych do tej pory wojowników pokonał w walce Saracenów i opanował Nîmes ${ }^{56}$.

Do pewnego stopnia podobna jest dziewiąta nowela dziesiątego dnia Dekameronu ${ }^{57}$. Gdy wieści o szykującej się III krucjacie dotarły

ca/SESDEF/miroir/tanase.pdf (dostęp: 17 VI 2019); J. Jacobs, An Inheritance of Violence, s. 304-307; Sh. Kinoshita, Beyond Philology, s. 33-35. O Wilhelmie, zob. J.H. Grisward, Archéologie de l'épopée médiévale. Structures trifonctionnelles et mythes indo-européens dans le cycle des Narbonnais, Paris 1981, s. 211-228.

${ }^{56}$ Le Charroi de Nîmes. Chanson de geste du Cycle de Guillaume d'Orange, wyd. C. Lachet, [Paris] 1999.

57 Zob. F. Fido, Il sorriso di Messer Torello („Decameron”, X,9), „Romance Philology” 23, 1969, 2, s. 154-171; C.L. Baskins, Scenes from a Marriage. Hospitality and Commerce in Boccaccio's Tale of Saladin and Torello, w: The Medieval Marriage Scene. Prudence, Passion, Policy, red. C.L. Baskins, S. Roush, Tempe 2005, s. 81-99; V.C. Ferme, Torello and the Saladin (X, 9). Notes on Panfilo, Day X, and the Ending Tale of the Decameron, w: Scales of Connectivity, red. P.M. Clogan, Lanham [etc.] 2009, s. 33-56; Sh. Kinoshita, „Noi siamo mercatanti cipriani”. How to do Things in the Medieval Mediterranean, w: Philippe de Mézières and His Age. Piety and Politics in the Fourteenth Century, red. R. Blumenfeld-Kosinski, K. Petkov, Leiden-Boston 
do Saladyna, sułtan Babilonu, dzielny wojownik (valentissimo signore), postanowił wyruszyć na przeszpiegi do Europy. Wybrał się tam w towarzystwie dwóch doradców i trzech sług, podając się za kupca. Postąpił zatem podobnie jak udający handlarzy kosztowności szpiedzy, dzięki którym świat chrześcijański stawał się transparentny dla pewnego sułtana Egiptu ${ }^{58}$. Gdy nasz bohater znalazł się w Lombardii, na drodze z Pawii do Mediolanu spotkał pewnego szlachcica nazwiskiem Torello di Stra da Pavia, który akurat polował z psami i sokołami. Szlachcic, widząc, że ma do czynienia $\mathrm{z}$ dostojnymi cudzoziemcami, postanowił ich odpowiednio ugościć. Zapytany przez Saladyna o drogę do Pawii, chytrze skierował go do własnej posiadłości, gdzie wraz z żoną uczcił ich biesiadą. Rozmowa szła gładko, ponieważ sułtan biegle władał łaciną (latino $)^{59}$. Spytany o profesję, Saladyn odparł, że jest cypryjskim kupcem („noi siamo mercatanti cipriani”), który zmierza do Paryża. Torello odparł na to, że dobrze byłoby, gdyby włoscy kupcy byli tak dostojni jak ci z Cypru. Gdy Saladyn chciał opuścić dwór, gospodarz przydzielił mu sługę, który zamiast do tawerny, zaprowadził go do drugiego domu swojego pana. Na cześć sułtana wydano kolejną ucztę. Podczas rozmowy z żoną Torella, Adalietą, Saladyn powtórzył, że jest kupcem z Cypru. Obdarowany pięknymi szatami, zaczął jednak podejrzewać, że gospodarz odkrył, kim gość jest naprawdę. Zrodziło się w nim też przekonanie, że gdyby wszyscy władcy chrześcijańscy byli tacy jak on, wówczas nie byłby w stanie w żaden sposób oprzeć się ich atakowi. Nad ranem wyruszył w dalszą drogę, odprowadzony przez świtę Torella. Ten ostatni rzekł na pożegnanie, niedwuznacznie zdradzając, że zdemaskował swoich gości: „Nie wiem, kim jesteście, i wbrew waszej woli nigdy nie będę próbował dowiedzieć się o tym. Nie wmówicie we mnie jednakowoż tego, że kupcami jesteście. A teraz Bogu was polecam!" W odpowiedzi usłyszał: „Kto to może wiedzieć, panie! Może zdołamy pokazać wam kiedyś nieco naszego towaru i przekonać was o prawdzie słów naszych; teraz zasię żegnamy was i również Panu Bogu polecamy".

2012, s. 41-59; B. Arduini, Messer Torello's Magic Carpet Ride as Synecdoche for Decameron 10.9, „Heliotropia” 16-17, 2019-2020, s. 189-204.

58 „il savoit tout l'estat des courtz des princes christiens et l'estat du comun par les gentz q'il envoie par toutes païs en gyse de marchantz des pieres preciouses et d'autres choses pur savoir le covigne de chescun païs", J. de Mandeville, Le Livre de merveilles du monde, wyd. C. Deluz, Paris 2000, s. 279, cyt. za: S. Gaunt, L’inquiétante étrangeté de la littérature de voyage en français au moyen âge, „Medioevo Romanzo” 34, 2010, 1, s. 4.

59 W sprawie języka, którym posługiwali się Saladyn i Torello, zob. K. Mallette, Lingua Franca, w: A Companion to Mediterranean History, red. P. Horden, Sh. Kinoshita, Chichester 2014, s. 332. 
Wówczas rozstali się, Saladyn zaś poprzysiągł sobie odpłacić Torellowi takimi samymi honorami, jakie spotkały go z jego strony (do takiego spotkania faktycznie dojdzie w Ziemi Świętej, nie będzie mnie ono jednak tutaj zajmować ${ }^{60}$.

Wojownicza natura wychodzi na jaw również w przypadku bohaterów starodolnoniemieckiego eposu Kudrun ${ }^{61}$. Jak czytamy, nad Hegelingami panował młody król Hettel. Ponieważ czuł się samotny, zasugerowano mu małżeństwo z irlandzką księżniczką Hildą. Szkopuł tkwił w tym, że wszyscy zalotnicy byli natychmiast zabijani przez jej zazdrosnego ojca, Hagena. Hettel zaproponował wobec tego, by jego wojownicy udali się do Irlandii pod pozorem, że są kupcami, których wyjął on spod prawa ${ }^{62}$. Postąpili tak, jak im polecono. Na miejscu rozstawili targowisko i przekazali dary królowi. Gdy Hagen dowiedział się, że zostali wygnani przez Hettela, podjął ich gościną. Podczas wydanej na ich cześć uczty jeden z nich, Horant, zaczął śpiewać. Jego pieśni tak urzekły Hildę, że następnego dnia poprosiła o jeszcze. Wówczas Horant wyjawił roztkliwionej królewnie, że jego pan jest wspaniałym władcą, który pragnie jej ręki dla siebie. W ten sposób zdobył jej serce dla króla. Następnie Hilda została uprowadzona na statek i przewieziona na dwór Hettela. Choć po drodze nie obyło się bez rozlewu krwi, cała historia zakończyła się szczęśliwie, ślubem króla z irlandzką królewną ${ }^{63}$.

Wysłannicy Hettela podawali się za kupców, ale Hilda domyśliła się, że w rzeczywistości są wojownikami; powiedziała nawet o tym jednemu z nich ${ }^{64}$, który potem udawał, że nie potrafi posługiwać się bronią. Po raz kolejny okazuje się, że przebranie nie jest w stanie ukryć prawdziwej natury przebranego ${ }^{65}$. Prawda ta okazała się aktualna także podczas eskapady Florisa, podjętej - co warto podkreślić - również w celach

${ }^{60}$ G. Boccaccio, Il Decameron, wyd. A.F. Massèra, t. 2, Bari 1927, giornata decima, novella nona, s. 291-308; idem, Dekameron, tłum. E. Boyé, t. 2, Warszawa 1974, s. 362-382.

${ }^{61}$ Zob. C. Bornholdt, Engaging Moments. The Origins of Medieval Bridal-Quest Narrative, Berlin-New York 2005, s. 185.

${ }^{62}$ Zob. G. van Sweringen Baur, The Disguise Motif in the Germanic Hero-Sagas, „Scandinavian Studies and Notes" 4, 1917, 3, s. 225 n. Porównawczo o bohaterach literackich udających banitów: P. Żmudzki, Władca i wojownicy, s. 72-75; idem, Wojewodowie w Polsce i na Rusi. Współbrzmienie narracji historiograficznych a problem polsko-ruskich relacji kulturowych we wczesnym średniowieczu, w: Granica wschodnia cywilizacji zachodniej w średniowieczu, red. Z. Dalewski, Warszawa 2014, s. 460-464.

${ }^{63}$ Kudrun, cap. 5-8, st. 204-562, s. 47-114.

64 „Si sprach gezogenlîche: 'nu sît uns willekomen. | ich und der künic mîn herre hân daz wol vernomen, | ir sît vermüete helde von urliuge sêre. | nu sol an iu bedenken der künic [--] sîn lob und ouch sîn êre", ibidem, cap. 5, st. 335, s. 71.

${ }^{65}$ Ibidem, s. 74 n. 
matrymonialnych ${ }^{66}$. Otóż zakochany saraceński królewicz, udając handlarza, zdradził się po dwakroć, gdy poczęstowany posiłkiem, nie wykazywał apetytu. „Nie wydaje mi się, by to był kupiec”, oznajmiła spostrzegawcza gospodyni. Dzięki temu jednak nasz bohater mógł dowiedzieć się, że wcześniej w tym samym miejscu była jego ukochana, która zachowywała się podobnie jak on. Uprzejmi gospodarze poinformowali go zaś, w którym kierunku ją zabrano ${ }^{67}$.

W czterech przytoczonych przed chwilą opowieściach bohaterowie udają kupców, a ich podstęp w ostatecznym rozrachunku sprawdza się. Wilhelmowi powiodło się wydarcie miasta z rąk Saracenów, Saladynowi zaś przygotowanie sił do obrony przed krzyżowcami. Podobnie Hettel zdobył upragnioną narzeczoną, a Floris dotarł do miejsca, w którym uwięziono Blanchefleur. Paradoks polega na tym - a problem ten jawi się jako kluczowy - że każdy z tych bohaterów został zdemaskowany. Pierwszy ze względu na swój znak szczególny, pozostali trzej dlatego, że nie wyglądali i nie zachowywali się jak kupcy. Saladyn już na pierwszy rzut oka prezentował się dostojnie jak żaden ze znanych Torellowi kupców i sam rychło trafnie odczytał gesty pragnącego godnie go uczcić gospodarza. Nie tylko władał tym samym językiem, ale całym swoim zachowaniem zdradzał przynależność do tej samej rycerskiej wspólnoty kulturowej. Ludzie króla Hettela musieli zaś udawać, że nie potrafią posługiwać się bronią, by ich prawdziwa tożsamość nie wyszła na jaw. Wreszcie gospodyni, która rozpoznała Florisa, zdaje się wyrażać przekonanie, że człowiek parający się handlem nie byłby zdolny do miłości dworskiej i związanej z nią melancholii, za to po grubiańsku rzuciłby się na jedzenie. Nie wystarczy zatem powiedzieć, że szata określa postać pod względem społecznym; pozwala ona wprawdzie wejść bohaterowi w nową rolę na czas dokonywania podstępu, nie zmienia go jednak na wskroś i nie do poznania. Człowiek szlachetny nawet w przebraniu

${ }^{66}$ Podobnie dzieje się w czwartej noweli czwartego dnia Dekameronu: wnuk króla Sycylii, Gerbino, zakochał się na odległość w księżniczce Tunisu; aby zapewnić ją o uczuciu, jakie do niej żywił, wysłał do niej jednego ze swoich przyjaciół w przebraniu kupca (G. Boccaccio, Il Decameron, t. 1, giornata quarta, novella quarta, s. 302; idem, Dekameron, t. 1, s. 350). o „uwodzicielskiej strategii” (uma estratégia da sedução) w kontekście działań Wilhelma Krótkonosego pisze C.F.C. Carreto, Na encruzilhada dos signos. Imaginário urbano e retórica da cidade na litteratura medieval (séculos XII-XIII), „Discursos”, ser. 3 (Língua, cultura e sociedade), 7, 2006, s. 54.

${ }^{67}$ Floris and Blancheflor, w: Middle English Romances in Translation. Amis and Amiloun Athelston - Floris and Blancheflor - Havelok the Dane - King Horn - Sir Degare, wyd. i tłum. K. Eckert, Leiden 2015, s. 118-120, zwłaszcza s. 118, v. 416-420: „Sire, ze saide, nimstou no zeme | How pis child mourning sit? | Mete and drink he forzit.| Litel he etez and lasse he drinkez | He nis no marchaunt as me pinkez". 
plebejusza pozostanie szlachcicem, zgodnie z żelazną zasadą, że atrybut włożony w niewłaściwe ręce nie będzie działał jak należy ${ }^{68}$. Zwróćmy również uwagę na reakcję Wilhelma Krótkonosego, który wytargany za brodę, ubolewał nad upokorzeniem, jakim było dlań zniżenie się do bycia kupcem $^{69}$. Nie chodzi tylko o to, że został przez Saracenów zdemaskowany i zidentyfikowany jako wróg ${ }^{70}$, ale przede wszystkim, że potraktowano go niezgodnie z jego faktycznym, wysokim statusem, tylko jak tego, kogo udawał ${ }^{71}$. Czyli odwrotnie niż Saladyna, który podawał się za kupca z Cypru, a został przez Torella podjęty tak, jak należałoby podjąć sułtana Babilonu.

Sądzę, że zyskujemy oto dostęp do wizji idealnej społeczności, niemal kastowej, w której warstwy zajmujące się handlem i walką zbrojną były od siebie oddzielone nieprzebytym murem. $Z$ jednej strony szlachetni, mężni wojownicy, z drugiej nieokrzesani, pozbawieni ogłady, nawykli do luksusów kupcy. Analizowane opowieści mówią nam nie tylko o tym, jak w średniowieczu konstruowano narrację, ale również jak wyobrażano sobie podziały społeczne. Znaczenie tej obserwacji, już ze względu na samą rozległość materiału porównawczego, na którym ją oparto, mocno wykracza poza realia norweskie. Może się zatem wydawać, że daleko odbiegliśmy od przekazu wyjściowego. Nasuwa się wobec tego pytanie, jak to wszystko ma się do potyczki w Saudungssundzie. Z całą pewnością można powiedzieć, że Olaf nie był naprawdę kupcem, tak jak nie byli nimi choćby Saladyn czy Floris - i to mimo że (w przeciwieństwie do nich,

68 Zob. J. Banaszkiewicz, „Zamach stanu w Gnieźnie”, czyli kilka uwag do wydania drugiego książki Podanie o Piaście i Popielu, w: idem, Podanie o Piaście i Popielu. Studium porównawcze nad wczesnośredniowiecznymi tradycjami dynastycznymi, wyd. 2, Warszawa 2010, s. 18-20; idem, Atrybuty i społeczne ordines, passim; P. Żmudzki, Władca i wojownicy, s. 434437; idem, Wędka króla Rusinów (Gall Anonim, ks. 1, rozdz. 7), St. Źr. 55, 2017, s. 27-50.

${ }^{69}$ Le Charroi de Nîmes, v. 1344-1351, s. 150.

70 Ibidem, v. 1335-1343, s. 150; por. A. Gronowska, „Fabuły rycerskie w Gesta ducum sive principum Polonorum Galla Anonima na tle wybranych przykładów piśmiennictwa średniowiecznego (do końca XIII w.)", praca doktorska, Uniwersytet Warszawski, Warszawa 2009, s. 48-63, gdzie szeroka analiza porównawcza opowieści Galla Anonima (I,23), w której Bolesław Szczodry wytargał za brodę ruskiego władcę identyfikowanego z Izjasławem.

${ }^{71}$ Jak - trochę uczenie, a trochę cum grano salis - zauważyła Anna Adamska, „typowe zaburzenie komunikacji westymentarnej stanowi niewłaściwa identyfikacja osób o wysokim statusie społecznym, ubranych nieadekwatnie do miejsca czy sytuacji, w jakich się znalazły. Ludzie ci reagują często charakterystycznym zdaniem: «Czy pan wie, kto ja jestem?» Błędne rozpoznanie ich tożsamości wynika z faktu, że ogólna wiedza o rzeczywistości i doświadczenie życiowe odbiorców komunikatu westymentarnego skłania ich do identyfikowania indywiduum w łachmanach raczej jako żebraka niż jako ekscentrycznego milionera czy profesora uniwersytetu", A. Adamska, op. cit., s. 20. 
a tak samo jak wielu innych bohaterów podobnych opowieści) nie został zdemaskowany. Powyższa uwaga może wydawać się banalna, wcale jednak taka nie jest. Ktoś mógłby bowiem podnieść, że handel był zajęciem ochoczo podejmowanym przez wikingów. Jednak nie w tym wypadku. W świetle zebranego materiału porównawczego trzeba odrzucić nasuwającą się interpretację, jakoby przyszły król Norwegii wyruszył z Anglii na łodziach towarowych w celu innym niż oszukanie przeciwnika (np. transport zrabowanych czy zakupionych uprzednio towarów, o czym źródła zresztą głucho milczą).

Poza tym wykorzystany w naszej opowieści wątek floty handlowej zbliża ją do narracji Herodota o zdobyciu Haliejs oraz Frontyna i Poliajnosa o zdobyciu Sykionu. Fakt, że to sam Haakon podpłynął do łodzi Olafa, odróżnia ją od innych wersji i przypomina o Askoldzie i Dirze, którzy zostali zwabieni w zasadzkę przez jednego z Rurykowiczów. Dobrej analogii nie znajduje „pacyfistyczny” wydźwięk podstępu norweskiego władcy, każący oceniać go z pewną dozą ambiwalencji. Pozostaje jeszcze motyw naciągniętej liny, który zajął w opowieściach o potyczce w Saudungssundzie tak poczesne miejsce, że kupiecki kamuflaż wojowników Olafa w ogóle nie zwrócił uwagi badaczy. Przyznajmy, ten element podstępu nie został przez autorów nadmiernie wyeksponowany, choć jest przecież w przekazach obecny. Teodoryk i autorzy kompendiów sag królewskich nie wykorzystali możliwości, jakie dawała im opowieść o wojownikach udających kupców. Aż do momentu, w którym Haakon wpadł w zasadzkę, nie doszło do zwyczajnej w takich przypadkach konfrontacji między nim a „kupcami”, która by obfitowała w barwne literacko, a interesujące badawczo szczegóły. Mechanizm narracyjny został tym samym zredukowany do niezbędnego minimum, a przecież działa jak należy i wystarczy, by Haakon wpadł w kleszcze zastawionej na niego pułapki ${ }^{72}$.

72 Podobnie dzieje się w Sadze o Eymundzie. Jej tytułowy bohater, niegdysiejszy towarzysz św. Olafa, zaangażował się w dynastyczny konflikt na Rusi po stronie Jaricleifa. Gdy kolejne próby wyeliminowania starszego brata władcy, Burisleifa, nie powiodły się, Eymund wraz z kilkunastoma ludźmi przebrał się za kupców i pod osłoną nocy zakradł pod obóz wroga. Zastanawia to, że pomiędzy obydwiema stronami nie doszło do żadnej konfrontacji, która by uzasadniała użycie takiego fortelu. Eymund natomiast samotnie, podając się za żebraka, wszedł na teren obozu po to, by za pomocą napiętej liny wystrzelić w powietrze królewski namiot (oczywiście pełni ona inną funkcję niż w opowieści o Olafie i Haakonie), Vikings in Russia. Yngvar's Saga and Eymund's Saga, wstęp i tłum. H. Palsson, P. Edwards, Edinburgh 1989, s. 81-84; por. P. Żmudzki, Władca i wojownicy, s. 268. Porównawczo o bohaterach przebranych za żebraków - G. van Sweringen Baur, op. cit., s. 223-225. 


\section{Streszczenie}

Przedmiotem rozważań jest zanotowana w kronice Mnicha Teodoryka (koniec XII w.) i w sagach królewskich (koniec XII w. - pierwsza połowa XIII w.) opowieść o potyczce w Saudungssundzie (ok. 1015 r.). Święty Olaf złapał wówczas w zasadzkę jarla Haakona Erikssona i wymusił na nim zrzeczenie się władzy nad częścią Norwegii. W ramach analizy komparatystycznej uwypuklono trzy aspekty niedługiej narracji. Po pierwsze, użycie podstępu w celu bezkrwawego pokonania przeciwnika. Po drugie, techniczną stronę zasadzki (zatrzymanie łodzi Haakona za pomocą liny rozciągniętej w poprzek cieśniny). Po trzecie wreszcie, fakt, że Haakon dał się złapać, ponieważ ludzie Olafa udawali kupców. Pokazano, że ten rodzaj podstępu jest często spotykanym motywem w literaturze starożytnej i średniowiecznej i może posłużyć jako przyczynek do wyobrażeń o ówczesnych podziałach społecznych (a konkretnie o powinnościach stanu kupieckiego i wojowniczego).

\section{Victory without Battle and Warriors Disguised as Merchants: Olaf the Saint's Deception at Saudungssund}

The article deals with the story of the skirmish at Saudungssund (c. 1015), recorded in Theodoricus Monachus' Chronicle (end of the twelfth century) and in the Kings Sagas (end of the twelfth century - first half of the thirteenth century). Saint Olaf then ambushed Earl Hákon Eriksson and forced him to relinquish his power over part of Norway. The comparative analysis emphasises three aspects of the short narrative: first, the use of deception to defeat an opponent bloodlessly. Secondly, the technical side of the ambush (stopping Hákon's vessel with a rope stretched across the strait). Thirdly and finally, the fact that Hákon's allowed himself to be caught because Olaf's men were pretending to be merchants. It has been shown that this kind of deception is a common motif in ancient and medieval literature, and the text can contribute to ideas about the social divisions of the time (specifically, the duties of the merchant and warrior estates).

\section{Bibliografia}

\section{Edycje źródłowe}

Ágrip af Nóregskonungasogum. A twelfth-century synoptic history of the kings of Norway, wyd. i tłum. Matthew J. Driscoll, Viking Society for Northern Research, London 2008.

The Anglo-Saxon Chronicle. A collaborative edition, wyd. Susan Irvine, t. 7, Ms. E, Brewer, Cambridge 2004.

Apollodorus, The Library, wyd. James G. Frazer, t. 2, William Heinemann Ltd., London 1921. 
Boccaccio Giovanni, Dekameron, tłum. Edward Boyé, t. 1-2, PIW, Warszawa 1974.

Boccaccio Giovanni, Il Decameron, wyd. Aldo F. Massèra, t. 1-2, Bari 1927.

Brennu-Njálssaga (Njála), wyd. Finnur Jónsson, Altnordische Saga Bibliothek, Halle a.S. 1908.

Le Charroi de Nîmes. Chanson de geste du Cycle de Guillaume d'Orange, wyd. Claude Lachet, Gallimard, [Paris] 1999.

Chronica Albrici monachi Trium Fontium, wyd. Paul Scheffer-Boichorst, Hannoverae 1874 (MGH SS, t. 23).

Chronicon Æthelweardi, wyd. i tłum. Alistair Campbell, Nelson, London [etc.] 1962.

A Commentary on Lucan, „De bello civili” IV. Introduction, Edition, and Translation, wyd. Paolo Asso, Berlin-New York 2010.

Fagrskinna. Nóregs kononga tal, wyd. Finnur Jónsson, København 1902-1903.

Floris and Blancheflor, w: Middle English Romances in Translation. Amis and Amiloun Athelston - Floris and Blancheflor - Havelok the Dane - King Horn - Sir Degare, wyd. i tłum. Kenneth Eckert, Sidestone Press, Leiden 2015.

Frontinus, The Stratagems, wyd. i tłum. Charles E. Bennett, London 1925.

Herodot, Dzieje, tłum. Seweryn Hammer, Czytelnik, Warszawa 1954.

Komarnicki Zygmunt, Legenda o ucieczce Samuela Koreckiego z niewoli tureckiej (wyjatek $z$ tomu XV Roczników kościelnych Baroniusza, dopetnionych przez Abrahama Bzowskiego, i z łacińskiego na język polski przełożony, „Biblioteka Warszawska” 61, 1856, 1, s. 179-188.

Kudrun, wyd. Karl Stackmann, M. Niemeyer, Tübingen 2000.

Legenda maior, wyd. Emericus Szentpétery, Budapestini 1938 (Scriptores rerum Hungaricarum, t. 2).

de Mandeville Jean, Le Livre de merveilles du monde, wyd. Christiane Deluz, CNRS Editions, Paris 2000.

Mnich Teodoryk, o starożytności norweskich królów. De antiquitate regum Norwagiensium, tłum. Rafał Rutkowski, Wydawnictwo Naukowe UMK, Torun 2021.

S. Odonis abbatis Cluniacensis De Vita s. Geraldi Auriliacensis comitis libri quatuor, PL, t. 133, Parisiis 1881.

Olafs Saga hins helga, wyd. Oscar A. Johnsen, Kristiania 1922.

Origo gentis Langobardorum, wyd. Georg Waitz, Hannoverae 1878 (MGH Scriptores rerum Langobardicarum, t. 1).

Poliajnos, Podstępy wojenne, tłum. Małgorzata Borowska, Prószyński i S-ka, Warszawa 2003.

Saxo Grammaticus, Gesta Danorum. The History of the Danes, wyd. Karsten Friis-Jensen, tłum. Peter Fisher, t. 1-2, Oxford 2015.

The Sháhnáma of Firdausi, tłum. Arthur G. Warner, Edmond Warner, t. 1-9, London 1905-1925.

Snorri Sturluson, Heimskringla. Nóregs Konunga Sögur, wyd. Finnur Jónsson, t. 2, København 1893-1900.

Theodoricus, De antiquitate regum Norwagiensium. On the Old Norwegian Kings, wyd. Egil Kraggerud, tłum. Peter Fisher, Novus Forlag, Oslo 2018.

Thomas de Aquino, De regimine principum (De regno ad regem Cypri), w: idem, Opuscula Philosophica, wyd. Raymundi M. Spiazzi, Marietti, Turin 1954. 
Vikings in Russia. Yngvar's Saga and Eymund's Saga, wstęp i tłum. Hermann Palsson, Paul Edwards, Edinburgh University Press, Edinburgh 1989.

Wyspiański Stanisław, Achilleis. Sceny dramatyczne, nakład autora, Kraków 1903.

Новгородская Первая Летопись, wyd. Арсений Н. Насонов, Москва-Ленинград 1950.

Повєсть временныхъ лєт, wyd. Дмитрий С. Лихачев, Москва-Ленинград 1950.

\section{Opracowania}

Adamska Anna, „Czy Pan wie, kto ja jestem?”. Kilka uwag o mechanizmach percepcji wzrokowej i skuteczności kodów westymentarnych w późnośredniowiecznej Europie, w: Habitus facit hominem. Społeczne funkcje ubioru $w$ średniowieczu i w epoce nowożytnej, red. Ewa Wółkiewicz, Monika Saczyńska, Marcin R. Pauk, Wydawnictwo IAE PAN, Warszawa 2016, s. 19-34.

Arduini Beatrice, Messer Torello's Magic Carpet Ride as Synecdoche for Decameron 10.9, „Heliotropia” 16-17, 2019-2020, s. 189-204.

Bagge Sverre, Nordic Uniqueness in the Middle Ages? Political and Literary Aspects, „Gripla" 20, 2009, s. 49-76.

Bagge Sverre, Theodoricus Monachus - Clerical Historiography in Twelfth-Century Norway, „Scandinavian Journal of History” 14, 1989, 2, s. 113-133.

Bagge Sverre, Theodoricus Monachus. The Kingdom of Norway and the History of Salvation, w: Historical Narratives and Christian Identity on a European Periphery. Early History Writing in Northern, East-Central and Eastern Europe (c. 1070-1200), red. Ildar H. Garipzanov, Brepols, Turnhout 2011, s. 71-90.

Banaszkiewicz Jacek, „Zamach stanu w Gnieźnie”, czyli kilka uwag do wydania drugiego książki Podanie o Piaście i Popielu, w: idem, Podanie o Piaście i Popielu. Studium porównawcze nad wczesnośredniowiecznymi tradycjami dynastycznymi, wyd. 2, PWN, Warszawa 2010, s. 9-24.

Banaszkiewicz Jacek, Atrybuty i społeczne ordines. Kilka obrazków z X-XI wieku, w: idem, Trzy po trzy o dziesiątym wieku, Avalon, Kraków 2014, s. 221-240.

Barthes Roland, Wstẹp do analizy strukturalnej opowiadań, tłum. Wanda Błońska, „Pamiętnik Literacki” 59, 1968, 4, s. 327-359.

Bartusik Grzegorz, „Rómverja Saga - Saga o Rzymianach. Studium nad recepcją kultury łacińskiej w średniowiecznej Skandynawii”, praca doktorska, Uniwersytet Śląski w Katowicach, Katowice 2019.

Baskins Cristelle L., Scenes from a Marriage. Hospitality and Commerce in Boccaccio's Tale of Saladin and Torello, w: The Medieval Marriage Scene. Prudence, Passion, Policy, red. Cristelle L. Baskins, Sherry Roush, Arizona Center for Medieval and Renaissance Studies, Tempe 2005, s. 81-99.

Bornholdt Claudia, Engaging Moments. The Origins of Medieval Bridal-Quest Narrative, de Gruyter, Berlin-New York 2005.

Brzozowska Magdalena, „Mnich czy arystokrata? Wzór świętości w «Żywocie św. Geralda» autorstwa Odona z Cluny", praca doktorska, Uniwersytet Warszawski, Warszawa 2016. 
Burns E. Jane, Sea of Silk. A Textile Geography of Women's Work in Medieval French Literature, University of Pennsylvania Press, Philadelphia 2009.

Carreto Carlos F.C., Na encruzilhada dos signos. Imaginário urbano e retórica da cidade na litteratura medieval (séculos XII-XIII), „Discursos”, ser. 3 (Língua, cultura e sociedade), 7, 2006, s. 51-84.

Czamańska Ilona, Kampania mołdawska Samuela Koreckiego 1615-1616 r., w: Si vis pacem, para bellum. Bezpieczeństwo i polityka Polski. Księga jubileuszowa ofiarowana Profesorowi Tadeuszowi Dubickiemu, red. Robert Majzner, Wydawnictwo Akademii im. Jana Długosza, Wydawnictwo Państwowej Wyższej Szkoły Zawodowej, Częstochowa-Włocławek 2013, s. 125-140.

Dubuisson Daniel, Twentieth Century Mythologies. Dumézil, Lévi-Strauss, Eliade, Routledge, London-New York 2014.

Duczko Władysław, Moce wikingów, t. 1: Światy i zaświaty wczesnośredniowiecznych Skandynawów, Instytut Wydawniczy Erica, Warszawa 2016.

Duczko Władysław, Zajęcie? Wiking. O ekonomicznej stronie ekspansji Skandynawów we wczesnym średniowieczu, w: Targi, jarmarki i odpusty. Wykłady popularnonaukowe zorganizowane w ramach X Ogólnopolskiego Festiwalu Kultury Słowiańskiej i Cysterskiej w Ladzie nad Warta $w$ dniach 31 maja - 1 czerwca 2014 roku, red. Michał Brzostowicz, Maciej Przybył, Jacek Wrzesiński, Muzeum Archeologiczne, Poznań-Ląd 2014, s. 43-51.

Dumézil Georges, Bogowie Germanów. Szkice o kształtowaniu się religii skandynawskiej, tłum. Anna Gronowska, wstęp Jacek Banaszkiewicz, Oficyna Naukowa, Warszawa 2006.

Ferme Valerio C., Torello and the Saladin (X, 9). Notes on Panfilo, Day X, and the Ending Tale of the Decameron, w: Scales of Connectivity, red. Paul M. Clogan, Lanham [etc.] 2009, s. 33-56.

Fido Franco, Il sorriso di Messer Torello („Decameron”, X,9), „Romance Philology” 23, 1969, 2, s. 154-171.

Foote Peter, Introduction, w: Theodoricus Monachus, An Account of the Ancient History of the Norwegian Kings, tłum. David McDougall, Ian McDougall, Viking Society for Northern Research, University College London, London 1998, s. VII-XXXI. Gaunt Simone, L'inquiétante étrangeté de la littérature de voyage en français au moyen âge, „Medioevo Romanzo” 34, 2010, 1, s. 1-25.

Grisward Joël H., Archéologie de l'épopée médiévale. Structures trifonctionnelles et mythes indo-européens dans le cycle des Narbonnais, Payot, Paris 1981.

Gronowska Anna, „Fabuły rycerskie w Gesta ducum sive principum Polonorum Galla Anonima na tle wybranych przykładów piśmiennictwa średniowiecznego (do końca XIII w.)", praca doktorska, Uniwersytet Warszawski, Warszawa 2009.

Helland Amund, Topografisk-statistik beskrivelse over Nordre Bergenhus Amt, t. 1, Kristiania 1901.

Jacobs Jason, An Inheritance of Violence. Patrimony, Vassal Service, and Conquest in the Charroi de Nîmes, „Exemplaria” 24, 2012, 4, s. 293-312.

Kinoshita Sharon, "Noi siamo mercatanti cipriani”. How to do Things in the Medieval Mediterranean, w: Philippe de Mézières and His Age. Piety and Politics in the Fourteenth Century, red. Renate Blumenfeld-Kosinski, Kiril Petkov, Brill, LeidenBoston 2012, s. 41-59. 
Kinoshita Sharon, Beyond Philology. Cross-Cultural Engagement in Literary History and Beyond, w: A Sea of Languages. Rethinking the Arabic Role in Medieval Literary History, red. Suzanne Conklin Akbari, Karla Mallette, University of Toronto Press, Toronto-Buffalo 2013, s. 25-42.

Kinoshita Sharon, Romance in/and the Medieval Mediterranean, w: Thinking Medieval Romance, red. Katherine C. Little, Nicola McDonald, Oxford University Press, Oxford, UK-New York 2018, s. 187-202.

Kristjánsson Jónas, Um Fóstbrœðrasögu, Reykjavík 1972.

Kuźmiuk-Ciekanowska Agnieszka, Święty $i$ historia. Dynastia Przemyślidów i jej bohaterowie w dziele mnicha Krystiana, Avalon, Kraków 2007.

Lange Gudrun, Die Anfänge der isländisch-norwegischen Geschichtsschreibung, Bókaútgáfa Menningarsjóđs, Reykjavík 1989.

Lönnroth Lars, Njáls Saga. A Critical Introduction, University of California Press, Berkeley 1976.

Losnegård Gaute, Askvoll during the Viking Period, https://encyclopedia.fylkesarkivet. no/article/95ca4897-6ab8-42a2-a1e9-17cd6c65172a/ (dostęp: 8 XII 2021).

Maddox Donald, Sturm-Maddox Sara, Inter textual Discourse in the William Cycle, „Olifant" 7, 1979, 2, s. 131-148.

Mallette Karla, Lingua Franca, w: A Companion to Mediterranean History, red. Peregrine Horden, Sharon Kinoshita, Wiley Blackwell, Chichester 2014, s. 330-344.

Manikowska Halina, Topos czy rzeczywistość? O czarnej śmierci w Dekameronie raz jeszcze, „Studia Źródłoznawcze” 53, 2015, s. 17-54.

Masques et déguisements dans la littérature médiévale, red. Marie-Louise Ollier, Les Presses de l'Université de Montréal, Librairie philosophique J. Vrin, MontréalParis 1988.

McLanathan Richard B.K., „Achilles on Skyros” by Nicolas Poussin, „Bulletin of the Museum of Fine Arts” 45, 1947, 259, s. 2-11.

Meulder Marcel, Le „cheval de Troie” sous une autre forme. Le guerrier déguisé en marchand. Exemples antiques et médiévaux, „Nouvelle Mythologie Comparée” 2013, 1, s. 1-42.

Michalski Wojciech, Robert Bruce i jego kompania w eposie pióra Johna Barboura. The Bruce około 1376 roku, Wydawnictwo UMCS, Lublin 2020.

Moos Peter von, Das mittelalterliche Kleid als Identitätssymbol und Identifikationsmittel, w: Unverwechselbarkeit. Persönliche Identität und Identifikation in der vormodernen Gesellschaft, red. Peter von Moos, Böhlau, Köln [etc.] 2004, s. 123-146.

Pac Grzegorz, Problem świętości władców we wczesnym i pełnym średniowieczu - przypadek Polski na tle europejskim, „Historia Slavorum Occidentis” 2016, 2 (11), s. $90-121$.

Pauk Marcin R., Habitus facit hominem - wprowadzenie do problematyki społecznych funkcji ubioru w epoce przednowoczesnej, w: Habitus facit hominem. Społeczne funkcje ubioru $w$ średniowieczu i w epoce nowożytnej, red. Ewa Wółkiewicz, Monika Saczyńska, Marcin R. Pauk, Wydawnictwo IAE PAN, Warszawa 2016, s. 7-17.

Perfetti Lisa R., Dialogue of Laughter. Bakhtin's Theory of Carnival and the Charroi de Nîmes, „Olifant” 17, 1993, 3-4, s. 177-195.

Renard John, Islam and the Heroic Image. Themes in Literature and the Visual Arts, University of South Carolina Press, Macon, GA 1999. 
Rutkowski Rafał, Norweska kronika Mnicha Teodoryka. Północna tradycja historyczna wprowadzona w nurt dziejów powszechnych (koniec XII wieku), Wydawnictwo Naukowe UMK, Toruń 2019.

Schach Paul, Instant Saga Style. The Evidence of the Manuscripts, "Journal of English and Germanic Philology" 85, 1986, 3, s. 404-420.

Suard François, Le Motif du déguisement dans quelques chansons du cycle de Guillaume d'Orange, „Olifant” 7, 1980, 4, s. 343-358.

van Sweringen Baur Grace, The Disguise Motif in the Germanic Hero-Sagas, „Scandinavian Studies and Notes" 4, 1917, 3, s. 220-239.

Tanase Gabriela, Le marchand et la Sarassin - des miroirs déformants de Guillaume d'Orange?, http://french.chass.utoronto.ca/SESDEF/miroir/tanase.pdf (dostęp: 17 VI 2019).

Ulset Tor, Det genetiske forholdet mellom „Ágrip”, „Historia Norwegice” og „Historia de antiquitate regum Norwagiensium". En analyse med utgangpunkt i oversettelsesteknikk samt en diskusjon omkring begrepet "latinisme” i samband med norrøne tekster, Novus, Oslo 1983.

Yorke Barbara, Wessex in the Early Middle Ages, Leicester University Press, LondonNew York 1995.

Żmudzki Paweł, Wędka króla Rusinów (Gall Anonim, ks. 1, rozdz. 7), „Studia Źródłoznawcze" 55, 2017, s. 27-50.

Żmudzki Paweł, Władca i wojownicy. Narracje o wodzach, drużynie $i$ wojnach $w$ najdawniejszej historiografii Polski i Rusi, Wydawnictwo UWr, Wrocław 2009.

Żmudzki Paweł, Wojewodowie w Polsce i na Rusi. Współbrzmienie narracji historiograficznych a problem polsko-ruskich relacji kulturowych we wczesnym średniowieczu, w: Granica wschodnia cywilizacji zachodniej w średniowieczu, red. Zbigniew Dalewski, IH PAN, Warszawa 2014, s. 435-465.

Агишев Сергей Ю., Теодорик Монах и его „История о древних норвежских королях”, Русский Фонд Содействия Образованию и Науке, Москва 2013.

Орловъ Александр С., Сказочныя повпсти объ Азовп. „Исторія” 7135 года, Варшава 1906.

Рыдзевская Елена А., К вопросу об устных преданиях в составе древнейшей русской летописи, w: eadem, Древняя Русь и Скандинавия IX-XIV вв., Наука, Москва 1978, s. 159-236.

Толочко Петр П., Двориовые интриги на Руси, Алетейя, Киев 2001.

Biogram: dr Rafał Rutkowski - pracownik Instytutu Archeologii i Etnologii PAN (Warszawa) i Uniwersytetu Warszawskiego. Zainteresowania badawcze: historia historiografii średniowiecznej, historia średniowiecznej Skandynawii, kultura intelektualna XII-XIII w.; kontakt: rr.rutkowski@wp.pl.

Author: Rafał Rutkowski, PhD, a research fellow at the Institute of Archaeology and Ethnology of the Polish Academy of Sciences (Warsaw). Research interests: history of medieval historiography, history of medieval Scandinavia, intellectual culture of the twelfth-thirteenth centuries; contact: rr.rutkowski@wp.pl. 